\title{
MITHRAS: A brief description
}

\author{
O. de la Beaujardière, ${ }^{1}$ V. B. Wickwar, ${ }^{1}$ M. J. Baron,${ }^{1,2}$ J. Holt,${ }^{3}$ R. M. Wand,${ }^{3}$ W. L. Oliver, ${ }^{3}$ P. Bauer, ${ }^{4}$ \\ M. Blanc, ${ }^{4}$ C. Senior, ${ }^{4}$ D. Alcayde, ${ }^{5}$ G. Caudal, ${ }^{4}$ J. Foster,,${ }^{6,7}$ E. Nielsen, ${ }^{8}$ and R. Heelis ${ }^{9}$
}

(Received July 19, 1983; revised October 28, 1983; accepted October 28, 1983.)

\begin{abstract}
Between May 1981 and June 1982 an intensive campaign of 33 coordinated observations was carried out using the three incoherent-scatter radars capable of probing the auroral zone. During this period the groups operating the Dynamic Explorer satellites and the STARE radar made special efforts to acquire data coincident with the radar observations. The objective of these MITHRAS experiments and subsequent analysis is to further our understanding of the interactions of the magnetosphere, the ionosphere, and the thermosphere, with special emphasis on local time/universal time variations. Three experimental modes with different time resolution and spatial coverage were used to examine different aspects of these interactions. The analysis of the extensive data set involves collaboration among groups of experimenters as well as between experimenters and theoreticians.
\end{abstract}

\section{INTRODUCTION}

The purpose of the MITHRAS (MagnetosphereIonosphere-Thermosphere Radar Studies) project is to study in detail the high-latitude upper atmosphere using primarily three incoherent-scatter systems: Chatanika (Alaska); Millstone Hill (Massachusetts); and EISCAT (Scandinavia), the European Incoherent Scatter facility. The coordinated experiments were motivated by a need to better understand the coupling between the magnetosphere, the ionosphere, and the thermosphere. The upper atmosphere forms a dynamic system of considerable complexity which, so far, has hindered efforts to fully understand how this coupling takes place. A proper combination of detailed and complete observations, together with theoretical modeling, is necessary for progress to be made. Simultaneous experiments from different sites are necessary to resolve ambiguities between local

\footnotetext{
${ }^{1}$ SRI International.

2 Now at EISCAT Scientific Association.

${ }^{3}$ Northeast Radio Observatory Corporation, Haystack Observatory.

${ }^{4}$ Centre National d'Etudes des Télécommunications/Centre de Recherches sur la Physique de l'Environnement.

${ }^{5}$ Centre d'Etude Spatiale des Rayonnements.

${ }^{6}$ Utah State University.

${ }^{7}$ Now at Haystack Observatory.

- Max-Planck-Institut für Aeronomie.

${ }^{9}$ University of Texas at Dallas.
}

Copyright 1984 by the American Geophysical Union.

Paper number 3S1740.

0048-6604/84/003S-1740\$08.00 time and universal time dependence of the observations.

The incoherent-scatter radar is a powerful research tool for the study of auroral zone phenomena such as ion convection, discrete and diffuse auroras, the midlatitude trough, field-aligned currents, and neutral atmospheric circulation. The radars provide data over an extended altitude range and a wide geographical area. The radars enable us to observe the evolution of events with a time resolution of a few minutes to a few tens of minutes.

Measurements from the Scandinavian Twin Auroral Radar Experiment (STARE) were also utilized. STARE operates continuously and can measure electric fields over a large portion of Scandinavia [Greenwald et al., 1978]. In addition, arrangements were made for the operation of the Dynamics Explorer (DE) satellites during the MITHRAS observations.

The Chatanika, Millstone Hill, and EISCAT systems have been described by Leadabrand et al. [1972], Evans et al. [1979], and Folkestad et al. [1983], respectively. The techniques to infer ionospheric parameters from the direct measurements are documented by Wickwar [1975], de la Beaujardière et al. [1980], and Holt et al. [1983a]. While Chatanika and Millstone are monostatic, EISCAT is tristatic. It comprises a transmitter-receiver station in Tromse, Norway, and receiving stations in Kiruna, Sweden, and Sodankylä, Finland.

As illustrated in Figure 1, Chatanika and EISCAT are about 11 hours apart in magnetic local time (MLT), and Millstone Hill precedes Chatanika and follows EISCAT by more than 6 hours. Chatanika 


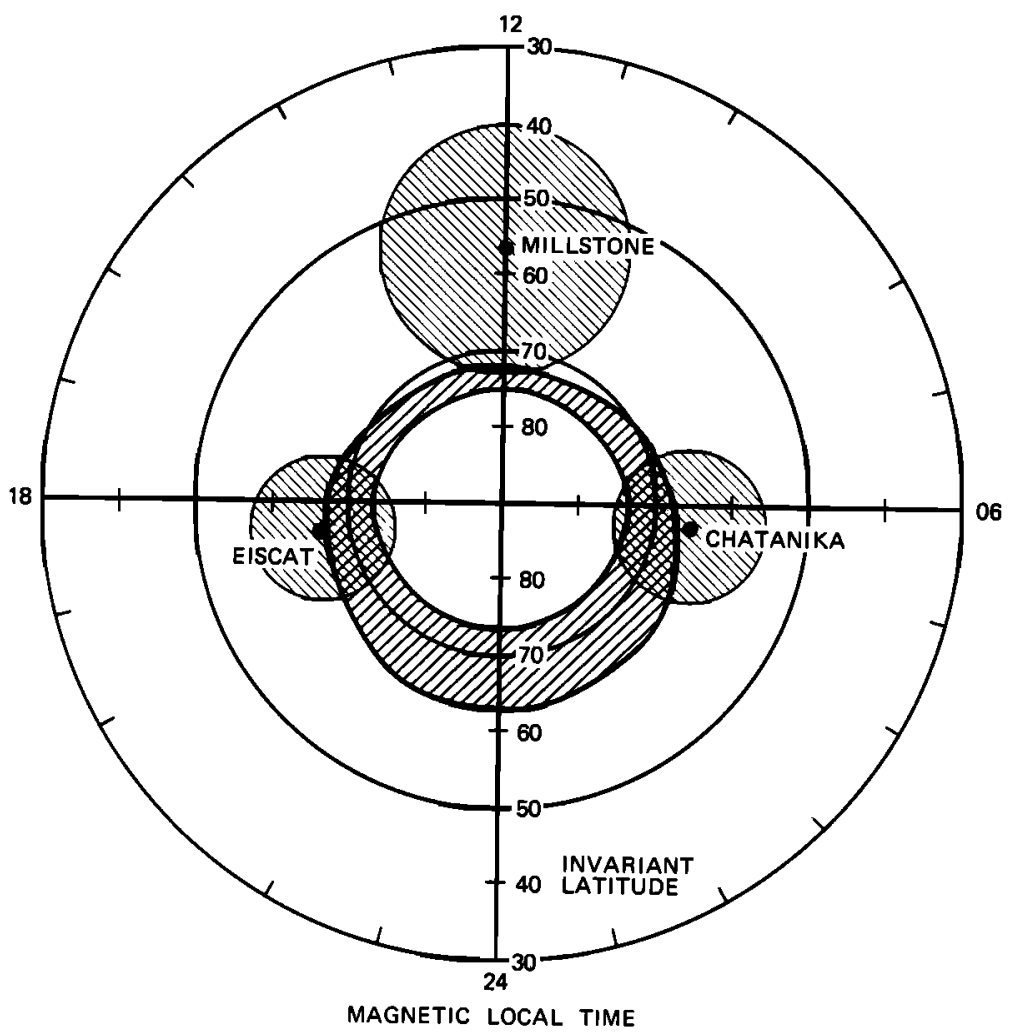

Fig. 1. MLT-invariant latitude plot of the positions of the EISCAT, Chatanika, and Millstone Hill radars when Millstone Hill is at magnetic noon. The auroral oval is that of Feldstein and Starkov [1968], for moderate activity $(Q=5)$. The small circles represent the $F$ region area probed at $500-\mathrm{km}$ altitude and with an elevation of $4^{\circ}$, $20^{\circ}$, and $20^{\circ}$ for Millstone, Chatanika, and EISCAT, respectively. MLT was computed for the month of June.

and EISCAT are both located at about $65^{\circ}$ invariant latitude, where they can probe the auroral zone in the $E$ and $F$ regions. Millstone Hill is located at $55^{\circ}$ invariant latitude and can probe the auroral zone only in the $F$ region. The coverage of the three radars at $500-\mathrm{km} \cdot$ altitude, and the auroral oval for moderate activity are also shown in Figure 1 . The geographic and geomagnetic coordinates of the stations are listed in Table 1.

In this paper we describe the experimental modes and objectives, provide a catalog of the MITHRAS observations, and then briefly summarize some of the MITHRAS scientific results. MITHRAS is described in greater detail by de la Beaujardière et al. [1982].

\section{EXPERIMENTAL MODES}

Three distinct experiments were designed and carried out for the MITHRAS program; each had a different primary objective resulting in different spatial coverage and time resolution. Operating modes consistent with the experiment objectives were de- signed for Chatanika, Millstone Hill, and EISCAT. The objectives and operating modes are outlined in Table 2.

MITHRAS 1. This experiment was designed to provide $F$ region measurements with the broadest

TABLE 1. Coordinates for Chatanika, EISCAT, and Millstone Hill Facilities

\begin{tabular}{lccc}
\hline \multicolumn{1}{c}{ Parameter } & Chatanika & $\begin{array}{c}\text { EISCAT } \\
\text { (Tromsø) }\end{array}$ & $\begin{array}{c}\text { Millstone } \\
\text { Hill }\end{array}$ \\
\hline Geographic latitude & $65.1^{\circ} \mathrm{N}$ & $69.5^{\circ} \mathrm{N}$ & $42.6^{\circ} \mathrm{N}$ \\
Geographic longitude & $147.5^{\circ} \mathrm{W}$ & $19.2^{\circ} \mathrm{E}$ & $71.5^{\circ} \mathrm{W}$ \\
Invariant latitude, $\Lambda^{*}$ & $65.1^{\circ}$ & $66.3^{\circ}$ & $55.2^{\circ}$ \\
Dipole geomagnetic longitude & $105^{\circ} \mathrm{W}$ & $105^{\circ} \mathrm{E}$ & $1.5^{\circ} \mathrm{W}$ \\
$\Lambda$ coverage at $350-\mathrm{km}$ altitude & $56^{\circ}-74^{\circ}$ & $61^{\circ}-71^{\circ} \dagger$ & $42^{\circ}-70^{\circ}$ \\
$L$ value & $5.6^{\circ}$ & $6.2^{\circ}$ & 3.1 \\
Dip angle & $77^{\circ}$ & $77.6^{\circ}$ & $70.5^{\circ}$ \\
Declination & $29^{\circ}$ & $-0.5^{\circ}$ & $-14.1^{\circ}$ \\
\hline
\end{tabular}

*At 300-km altitude.

†These numbers reflect the largest coverage for the vector velocity measurements during the MITHRAS operations. The coverage for density and temperature is wider. 
TABLE 2. The Three MITHRAS Experiments

\begin{tabular}{|c|c|c|c|c|c|}
\hline $\begin{array}{l}\text { Experi- } \\
\text { ment }\end{array}$ & Objective & $\begin{array}{l}\text { Time } \\
\text { Resolution, } \\
\text { min }\end{array}$ & Chatanika Mode & Millstone Hill Mode & EISCAT Mode \\
\hline 1 & $\begin{array}{l}\text { Widest latitudinal } \\
\text { coverage }\end{array}$ & 30 to 45 & $\begin{array}{l}11 \text { positions ( } 5 \text { pairs }+1 \\
\text { parallel to } B)\end{array}$ & $\begin{array}{l}350^{\circ} \text { azimuth scan at } 4^{\circ} \\
\text { elevation }\end{array}$ & $\begin{array}{l}\mathrm{CP}(3) \text {. Several positions }^{*} \\
\text { along plane at } 15^{\circ} \text { azimuth. } \\
\text { Remote antennas intersect } \\
\text { beam } F \text { region. }\end{array}$ \\
\hline 2 & $\begin{array}{l}\text { Shortest time } \\
\text { resolution }\end{array}$ & 10 & $\begin{array}{l}\text { Three positions (overhead } \\
\text { measurements); short-pulse } \\
\text { correlator for } E \text { region } \\
\text { parameters }\end{array}$ & $\begin{array}{l}\text { At two north azimuths, and } \\
\text { for elevations } 2^{\circ} \text { to } 17^{\circ} ; \\
E \text { and } F \text { region } \\
\text { measurements }\end{array}$ & $\begin{array}{l}\mathrm{CP}(0) \text { or } \mathrm{CP}(-1) \text {. Tromsø } \\
\text { beam parallel to } B \text {. Remote } \\
\text { antennas intersect at } \\
\text { heights } 110 \text { to } 700 \mathrm{~km} \text {. }\end{array}$ \\
\hline 3 & $\begin{array}{l}\text { Intermediate time } \\
\text { and latitude } \\
\text { resolution }\end{array}$ & 20 & $\begin{array}{l}\text { Elevation scan in meridian, } \\
\text { followed by scan to the west }\end{array}$ & $\begin{array}{l}180^{\circ} \text { azimuth scan north of } \\
\text { the station at } 4^{\circ} \text { elevation }\end{array}$ & $\mathrm{CP}(3)$ (same as 1 ). \\
\hline
\end{tabular}

* $\mathrm{CP}$ is common program. The numbers in parentheses are as follows: 0 or -1 for single position mode; 3 for three or more positions along a magnetic meridian; 2 for three positions, one above each antenna.

possible latitudinal coverage. Large-scale studies of electric fields, temperatures, and ionization were emphasized. The time resolution of this experiment was 30 to $45 \mathrm{~min}$.

The Chatanika radar was operated in an 11position mode [Foster et al., 1981]: five pairs of positions straddling the magnetic meridian plane, and one position parallel to the magnetic field, B. With this mode a large latitudinal coverage was possible in the $F$ region, and at the same time the $E$ region electrodynamic parameters could be determined close to the radar latitude. Every hour and a half, the radar was scanned in elevation in the magnetic meridian plane. This scan gave the cross section of the ionization profile as a function of height, with a fine latitudinal resolution.

The Millstone radar was operated at a fixed elevation (typically $4^{\circ}$ ) in an azimuth scan covering almost the full circle [Holt et al., 1983a]. This operating mode had the advantage that longitudinal effects could be studied by comparing the measurements to the east and to the west. In 1982 the azimuth scans were followed by an elevation scan, horizon to horizon, in the geographic meridian.

During the initial operations, EISCAT could only be run with simple operating modes. The mode used during this phase is described under the MITHRAS 2 experiments. In December 1981, some latitudinal coverage was achieved with the system. Starting in January, later versions consisted of 11 or 16 positions in the $15^{\circ}$ azimuth plane. The Sodankylä and Kiruna beams intersected the Tromso beam at $325-\mathrm{km}$ altitude.

MITHRAS 2. This experiment was directed pri- marily toward substorm studies of both the $E$ and $F$ regions with the best possible time resolution (10 min). To realize this time resolution, which is necessary to study substorm effects, this experiment concentrated on a narrow range of latitudes near the invariant latitude of Chatanika $\left(\Lambda=65^{\circ} \mathrm{N}\right)$. In addition to the $F$ region electric field, temperatures, densities, and meridional wind, a wide range of $E$ region parameters were obtained at Chatanika. These $E$ region parameters included conductivities, electron energy deposition rates, differential energy spectra of precipitating electrons, neutral winds, currents, and Joule heating. At Tromsø, some of these $E$ region parameters were also measured.

The operating mode for Chatanika consisted of a set of three positions, one parallel to the magnetic field and the two others on either side of the magnetic meridian at $70^{\circ}$ elevation [Rino et al., 1977]. The velocity and temperatures were obtained with a fine $(9-\mathrm{km})$ altitude resolution for $E$ region measurements, and with a coarser $(50-\mathrm{km})$ resolution for the $F$ region.

At Millstone Hill, initial observations were conducted at $4^{\circ}$ elevation using a $64^{\circ}$ azimuth scan centered north on the magnetic meridian. At $F$ region altitudes (200 to $500 \mathrm{~km}$ ) the resulting invariant latitude coverage was $61^{\circ}$ to $69^{\circ}$. Later, a second type of MITHRAS 2 program consisted of elevation scans from $2^{\circ}$ to $17^{\circ}$, at azimuths $15^{\circ}$ on either side of the magnetic meridian, covering the invariant latitudes from $60^{\circ}$ to $72^{\circ}$ for $F$ region altitudes. This program used a shorter pulse length at the lowest elevation angles in order to obtain $E$ region parameters.

The EISCAT transmitting antenna was held fixed, 
parallel to the magnetic field. For some experiments, the two receiving stations scanned the Tromsø beam at six discrete heights between $110-$ and $700-\mathrm{km}$ altitude. In other experiments the remote stations were held fixed, intersecting the Tromsø beam at about 300-km altitude.

MITHRAS 3. This experiment was directed at examining $E$ and $F$ region morphology with a time resolution between those afforded by programs 1 and 2 (i.e., about $20 \mathrm{~min}$ ). For Chatanika and EISCAT it provided latitudinal coverage for both $E$ and $F$ regions. It was useful in identifying and following the evolution of ionization features (e.g., diffuse aurora, trough, and $F$ region enhancements) as well as the variations of electric field, temperatures, currents, precipitating electron energy spectra, and the energy deposition rate associated with these features.

The Chatanika radar operated in a set of two scans [de la Beaujardière et al., 1981]. It completed one elevation scan in the magnetic meridian and then one scan to the west along a path such that at each invariant latitude the radar sampled the ionosphere at the same magnetic local time that was sampled during the elevation scan. The mode for EISCAT was the same as that for MITHRAS 1. Millstone scanned in azimuth over the $180^{\circ}$ north of the radar, at an elevation of $4^{\circ}$.

\section{CATALOG OF MITHRAS OBSERVATIONS}

A summary of MITHRAS operations at the three radars is given in Table 3 . The operating modes are identified by the descriptions listed in the previous section. The times listed are the start and end times at each radar. Twenty-nine MITHRAS experiments were made before Chatanika was disassembled in preparation for its move to Greenland. There are a total of 33 MITHRAS experiments, covering a period of just over 1 year. The first observations started before EISCAT was operational. By special agreement the MITHRAS observations were continued between Millstone and EISCAT after the Chatanika disassembly. The two-way and three-way overlap hours indicate the duration of the periods when data were collected at two of the three and at all three radars. The sum of the 3-hourly $K p$ values for each 24-hour period is listed to indicate the global magnetic conditions for the cooperative experiments. Fortunately, each experiment type occurred during both quiet and active geomagnetic conditions.

\section{PRELIMINARY SCIENTIFIC RESULTS}

The data analysis phase of the MITHRAS program has started. Among the preliminary results obtained we can cite the following:

Ionosphere. For a given electric field the $F$ region ion temperature tends to be higher in the postmidnight sector than in the premidnight sector. This asymmetry was explained by the fact that ion-neutral frictional heating is more pronounced and longer lasting in the morning than in the evening sector. In the evening, ion drag is more effective at coupling the neutrals to the ions; the time constant for the coupling is less than 1 hour. In the morning this time constant becomes very long, more than 7 hours, because of the low electron density. Thus the ion and neutral motions are essentially decoupled [Baron and Wand, 1983]. In a separate study, currently in progress, ionospheric densities and temperatures were compared for the three radars for selected periods, and between the radars and the model ionosphere of Elkins [1973]. In a third study, the nighttime $F$ region density was compared for the three radars. It was found that the densities were largest over EISCAT and were lowest over Millstone Hill. This inequality was attributed to the offset of the geographic and geomagnetic poles. When each radar is in the midnight sector, the corresponding cusp region is at a lower latitude for EISCAT than for Millstone. In other words, the relative positions of the terminator and the cusp determine how much ionization is contained in the flux tubes that convect across the polar cap [de la Beaujardière et al., 1983b].

Thermosphere. A method was developed to determine auroral zone values for the exospheric temperature and atomic oxygen concentration, even in the presence of Joule heating. These thermospheric parameters were obtained for several periods, and the EISCAT and Chatanika values compared [Alcaydé et al., 1982, 1983]. A study is now in progress to determine the seasonal and solar cycle dependence of the exospheric temperature, using EISCAT and Chatanika data.

The EISCAT and Chatanika meridional winds between 200 and $300 \mathrm{~km}$ have been compared to determine the major features and driving forces [Wickwar et al., 1983]. During the night there is a strong equatorward wind. The EISCAT/Chatanika comparison indicates that the wind is controlled to a large extent by magnetospheric effects, possibly arising from ion drag. During nights when the electric field was large, 
TABLE 3. MITHRAS Operations (May 1981 Through June 1982)

\begin{tabular}{|c|c|c|c|c|c|c|c|c|}
\hline \multirow[b]{2}{*}{ Day } & \multirow[b]{2}{*}{ Date* } & \multicolumn{3}{|c|}{ Time* (Start-End) } & \multirow{2}{*}{$\begin{array}{c}\text { Two-Way } \\
\text { Overlap, } † \\
\text { hours }\end{array}$} & \multirow{2}{*}{$\begin{array}{c}\text { Three-Way } \\
\text { Overlap, } \dagger \\
\text { hours }\end{array}$} & \multirow[b]{2}{*}{$\Sigma K p$} & \multirow[b]{2}{*}{ Mode } \\
\hline & & Chatanika & Millstone Hill & EISCAT & & & & \\
\hline 133 & May 13 & $0018-2400$ & $2135-$ & & 2.4 & $\cdots$ & $16-$ & MITHRAS 2 \\
\hline 134 & May 14 & & -0400 & & $\cdots$ & $\cdots$ & 25 & \\
\hline 143 & May 23 & $1555-$ & $1425-$ & & 8.1 & $\cdots$ & $25+$ & MITHRAS 1 \\
\hline 144 & May 24 & -1837 & -1950 & & 13.0 & $\cdots$ & $26+$ & \\
\hline 161 & June 10 & $0044-$ & $0005-$ & & 22.7 & $\cdots$ & 9 & MITHRAS 3 \\
\hline 162 & June 11 & -0130 & -0400 & & 1.5 & $\cdots$ & 13 & \\
\hline 174 & June 23 & $2050-2340$ & $2210-$ & & 1.5 & $\cdots$ & $10-$ & MITHRAS 2 \\
\hline 175 & June 24 & & - & & $\cdots$ & $\cdots$ & $19+$ & \\
\hline 176 & June 25 & & -0400 & & $\cdots$ & $\cdots$ & 22 & \\
\hline 178 & June 27 & $0358-$ & 0335- & & 19.7 & $\cdots$ & $20-$ & MITHRAS 1 \\
\hline 179 & June 28 & -0505 & -1725 & & 5.1 & $\cdots$ & 18 & \\
\hline 185 & July 4 & $0158-$ & $0210-$ & & 20.4 & $\cdots$ & $16-$ & MITHRAS 1 \\
\hline 186 & July 5 & -0358 & - & & 4.0 & $\cdots$ & $22-$ & \\
\hline 187 & July 6 & & -1215 & & $\cdots$ & $\cdots$ & $27-$ & \\
\hline 195 & July 14 & $2200-$ & & & $\cdots$ & $\ldots$ & $14-$ & MITHRAS 2 \\
\hline 196 & July 15 & - & $1510_{-}^{-}$ & & 8.8 & $\cdots$ & $7-$ & \\
\hline 197 & July 16 & -0012 & -1520 & & 0.2 & $\cdots$ & $16+$ & \\
\hline 202 & July 21 & $2152-$ & & & $\cdots$ & $\cdots$ & $13-$ & MITHRAS 3 \\
\hline 203 & July 22 & -2359 & $0112-$ & & 17.1 & $\cdots$ & $28+$ & \\
\hline 204 & July 23 & & -0030 & & $\cdots$ & $\cdots$ & $34-$ & \\
\hline 213 & Aug. 1 & & $0550-$ & & $\cdots$ & $\cdots$ & $26-$ & MITHRAS 1 \\
\hline 214 & Aug. 2 & 0208- & -2330 & & 20.8 & $\cdots$ & $22-$ & \\
\hline 215 & Aug. 3 & -0358 & & & $\cdots$ & $\cdots$ & 26- & \\
\hline 218 & Aug. 6 & & 0720 & & $\cdots$ & $\cdots$ & $21+$ & MITHRAS 3 \\
\hline 219 & Aug. 7 & & -0030 & & $\cdots$ & $\cdots$ & $17+$ & \\
\hline 223 & Aug. 11 & & $2005-$ & & $\cdots$ & $\ldots$ & $22+$ & MITHRAS 1 \\
\hline 224 & Aug. 12 & & - & & $\cdots$ & $\cdots$ & $18-$ & \\
\hline 225 & Aug. 13 & & -1125 & & $\cdots$ & $\cdots$ & $18+$ & \\
\hline 258 & Sept. 15 & & $1850-$ & & $\cdots$ & $\ldots$ & $17+$ & MITHRAS 1 \\
\hline 259 & Sept. 16 & & -2330 & $0900-$ & 14.5 & $\cdots$ & $15-$ & $\mathrm{CP}(-1)$ \\
\hline 260 & Sept. 17 & & & -0800 & $\cdots$ & $\cdots$ & 9 & \\
\hline 265 & Sept. 22 & & 1318- & & $\cdots$ & $\cdots$ & 20 & MITHRAS 3 \\
\hline 266 & Sept. 23 & & - & & $\cdots$ & $\cdots$ & $8+$ & \\
\hline 267 & Sept. 24 & & -1600 & & $\cdots$ & $\cdots$ & 16 & \\
\hline 272 & Sept. 29 & & 1949- & & $\cdots$ & $\cdots$ & $20+$ & MITHRAS 2 \\
\hline 273 & Sept. 30 & $0130-$ & - & $1130-$ & 18.9 & 12.5 & $24-$ & $\mathrm{CP}(-1)$ \\
\hline 274 & Oct. 1 & -0138 & -0346 & -0900 & 3.8 & 1.6 & 18 & \\
\hline 279 & Oct. 6 & & & $2200-$ & $\cdots$ & $\cdots$ & $12-$ & MITHRAS 3 \\
\hline 280 & Oct. 7 & $0011-$ & $2236-$ & -2120 & 13.4 & $\cdots$ & 32 & $\mathrm{CP}(-1)$ \\
\hline 281 & Oct. 8 & -1214 & -2400 & & 12.2 & $\cdots$ & 30 & \\
\hline 297 & Oct. 24 & & $0217-$ & & $\cdots$ & $\cdots$ & $22-$ & MITHRAS I \\
\hline 298 & Oct. 25 & $0031-$ & - & 1630 & 23.0 & 5.1 & $24+$ & $\mathrm{CP}(0)$ \\
\hline 299 & Oct. 26 & - & -1328 & -0900 & 13.0 & 8.5 & $18-$ & \\
\hline 300 & Oct. 27 & -0009 & & & $\cdots$ & $\cdots$ & 18 & \\
\hline 300 & Oct. 27 & & $2129-$ & & $\ldots$ & $\cdots$ & 18 & MITHRAS 2 \\
\hline 301 & Oct. 28 & $0004-$ & - & & 22.9 & $\cdots$ & 26 & \\
\hline 302 & Oct. 29 & -0200 & -0415 & & 2.0 & & 20 & \\
\hline
\end{tabular}


TABLE 3. (continued)

\begin{tabular}{|c|c|c|c|c|c|c|c|c|}
\hline \multirow[b]{2}{*}{ Day } & \multirow[b]{2}{*}{ Date* } & \multicolumn{3}{|c|}{ Time* (Start-End) } & \multirow{2}{*}{$\begin{array}{c}\text { Two-Way } \\
\text { Overlap, } \dagger \\
\text { hours }\end{array}$} & \multirow{2}{*}{$\begin{array}{c}\text { Three-Way } \\
\text { Overlap, } \dagger \\
\text { hours }\end{array}$} & \multirow[b]{2}{*}{$\Sigma K p$} & \multirow[b]{2}{*}{ Mode } \\
\hline & & Chatanika & Millstone Hill & EISCAT & & & & \\
\hline 314 & Nov. 10 & & 2130 & & $\cdots$ & $\cdots$ & $21-$ & MITHRAS 3 \\
\hline 315 & Nov. 11 & 0000 & - & $0900-1453$ & 21.9 & 5.9 & $32-$ & $\mathrm{CP}(0)$ \\
\hline 316 & Nov. 12 & -0213 & -0135 & & 1.6 & $\cdots$ & $30-$ & \\
\hline 321 & Nov. 17 & & $2124-$ & & $\cdots$ & $\cdots$ & $33+$ & MITHRAS 2 \\
\hline 322 & Nov. 18 & $0017-$ & - & $0900-$ & 22.6 & 15.0 & 31 & $\mathrm{CP}(0)$ \\
\hline 323 & Nov. 19 & -0001 & -0500 & -0900 & 5.0 & $\cdots$ & $23+$ & \\
\hline 325 & Nov. 21 & 0017 & $0312-$ & & 20.5 & $\cdots$ & $23+$ & MITHRAS 1 \\
\hline 326 & Nov. 22 & -0201 & - & & 1.9 & $\cdots$ & $19+$ & \\
\hline 327 & Nov. 23 & & -0926 & & $\cdots$ & $\cdots$ & 27 & \\
\hline 339 & Dec. 5 & $1702-$ & $0313-$ & & 4.2 & $\cdots$ & $17+$ & MITHRAS 1 \\
\hline 340 & Dec. 6 & -1707 & -0330 & & 3.5 & $\cdots$ & $8+$ & \\
\hline 342 & Dec. 8 & 2143- & $2235-$ & $1500-$ & 2.3 & 1.4 & $22+$ & MITHRAS 3 \\
\hline 343 & Dec. 9 & -2400 & -0456 & -2020 & 17.3 & 4.4 & $20-$ & $\mathrm{CP}(-3 e)$ \\
\hline 349 & Dec. 15 & $2241-$ & $2146-$ & $1500-$ & 2.2 & 1.3 & $10+$ & MITHRAS 2 \\
\hline 350 & Dec. 16 & - & - & -1940 & 21.5 & 17.2 & $9-$ & $C P(-3 s)$ \\
\hline 351 & Dec. 17 & -0010 & -0449 & & 0.2 & $\cdots$ & 11 & \\
\hline 9 & Jan. 9 & & 0305- & & $\cdots$ & $\cdots$ & 8 & MITHRAS 1 \\
\hline 10 & Jan. 10 & 0620 & - & & 17.7 & $\cdots$ & $7-$ & \\
\hline 11 & Jan. 11 & -0803 & -1418 & & 8.0 & $\cdots$ & $10+$ & \\
\hline 19 & Jan. 19 & 1800 & $2116-$ & & 2.7 & $\cdots$ & $6+$ & MITHRAS 2 \\
\hline $\begin{array}{l}20 \\
21\end{array}$ & $\begin{array}{l}\text { Jan. } 20 \\
\text { Jan. } 21\end{array}$ & -2005 & $\begin{array}{l}- \\
-0458\end{array}$ & $1500-2300$ & 19.7 & 1.2 & $\begin{array}{l}12+ \\
22\end{array}$ & $\mathrm{CP}(-3 \mathrm{e})$ \\
\hline 26 & Jan. 26 & $1818-$ & $2121-$ & 1500 & 5.7 & 2.7 & 13 & MITHRAS 3 \\
\hline 27 & Jan. 27 & - & - & -2258 & 24.0 & 21.0 & $21+$ & $\mathrm{CP}(3)$ \\
\hline 28 & Jan. 28 & -0010 & -0129 & & 0.2 & $\cdots$ & 24 & \\
\hline 30 & Jan. 30 & & $0306-$ & & $\cdots$ & $\cdots$ & 29 & MITHRAS 1 \\
\hline 31 & Jan. 31 & $0608-$ & - & $1000-2345$ & 15.6 & 12.4 & $34-$ & $\mathrm{CP}(3)$ \\
\hline 32 & Feb. 1 & -1320 & -1332 & & 13.3 & $\cdots$ & 34 & \\
\hline 40 & Feb. 9 & 1550 & $1042-$ & & 8.2 & $\cdots$ & 24 & MITHRAS 3 \\
\hline 41 & Feb. 10 & -2307 & -1512 & & 15.2 & $\cdots$ & $33+$ & \\
\hline 47 & Feb. 16 & $1805-$ & $2031-$ & & 3.5 & $\cdots$ & $13+$ & MITHRAS 2 \\
\hline 48 & Feb. 17 & - & - & & 23.4 & $\cdots$ & $30+$ & \\
\hline 49 & Feb. 18 & -0003 & -0459 & & $\cdots$ & $\cdots$ & $34+$ & \\
\hline 114 & April 24 & & 0441- & & & $\cdots$ & 21 & MITHRAS 1 \\
\hline 115 & April 25 & & - & 1210 & 10.0 & $\cdots$ & $37+$ & $\mathrm{CP}(3)$ \\
\hline 116 & April 26 & & -1227 & -1000 & 10.0 & $\cdots$ & $15-$ & \\
\hline 128 & May 8 & & $0153-$ & & & $\cdots$ & 10 & MITHRAS 1 \\
\hline 129 & May 9 & & -2000 & $1018-$ & 8.8 & $\cdots$ & 15 & $\mathrm{CP}(0)$ \\
\hline 130 & May 10 & & & -1003 & & $\cdots$ & $11-$ & \\
\hline 138 & May 18 & & $2008-$ & 1500 & 3.9 & $\cdots$ & $26+$ & MITHRAS 3 \\
\hline 139 & May 19 & & -2400 & -2300 & 23.0 & $\cdots$ & 21 & $\mathrm{CP}(-2)$ \\
\hline 140 & May 20 & & -0358 & & & $\cdots$ & 17 & \\
\hline 166 & June 15 & & $2012-$ & & & & 30 & MITHRAS 1 \\
\hline 167 & June 16 & & - & $1100-$ & 13.0 & $\cdots$ & $19+$ & $\mathrm{CP}(3)$ \\
\hline 168 & June 17 & & -0358 & -1100 & 4.0 & $\cdots$ & $13-$ & \\
\hline
\end{tabular}

*Dates and times are UT.

$\dagger$ Data gaps of $>20$ min duration excluded from overlap time calculation. 
there was a second equatorward wind increase that may have been related to Joule heating.

A study is now in progress concerning the electrodynamic parameters of the ionosphere/ magnetosphere system. This work involves a comparison of the MITHRAS electric fields measured at several longitudes with those deduced from the various International Magnetospheric Study chains of magnetometers. The technique to compute the global electric fields and field-aligned currents from the magnetometer data has been described by Kamide et al. [1982]. It is quite complex and relies heavily on a model of conductivity. The use of conductivities from Chatanika and EISCAT, along with those deduced from satellites, should be a significant improvement over the available models. The calculations will then be further constrained by having to obtain convection electric fields that match those from the three radars.

Magnetosphere. Detailed case studies dealt with the effect of substorms on convection. A three-radar comparison of the substorm electric field signature [de la Beaujardière et al., 1983a] revealed that the signature depends primarily on the local time when the observation is made. The cross-polar cap potential was also estimated from radar electric fields in the dawn or dusk sectors. In another study, it was shown that intense electric fields associated with substorms can be a dominant factor in the formation of ionospheric troughs [Holt et al., 1983b; Evans et al., 1983]. Subauroral electric fields were observed during a period of prolonged magnetic activity on November 11, 1981 [Senior, 1982]. For one MITHRAS period when the interplanetary magnetic field (IMF) components were south and away, Heelis et al. [1983] determined the large-scale ion convection using data from three radars in conjunction with several DE 2 passes. The dusk cell had a circular shape such that its poleward perimeter extended into the dawn sector. The dawn cell was smaller and crescent shaped. Another study also dealt with an extended period when the IMF was south and away (November 18, 1981). The electric fields seen by Chatanika, Millstone, and EISCAT were very intense in the dawn and dusk sectors, and the electric field reversal in the midnight sector occurred at a very early local time at the three radars. G. Caudal et al. (unpublished manuscript, 1983) suggest that for at least 10 hours the global plasma convection pattern remained fairly uniform and was expanded and rotated toward early hours.

Empirical models. Models are being constructed to characterize the day and night conductivities, the electric fields, the $E$ and $F$ region densities, and the exospheric temperature. These models yield average values of the latitudinal variations of the radar parameters. They depend on quantities such as $K p$, solar flux, IMF, solar zenith angle, and precipitation. Particular attention has been given to the average convection pattern [Foster, 1983; Oliver et al., 1983; J. M. Holt et al., unpublished manuscript, 1983]. In the work by Foster [1984] the average convection is mapped into the outer magnetosphere. These models are important in their own right, but they also provide a baseline to which particular data sets can be compared.

Theoretical model. A theoretical model of the temporal variation and global effects of ring current shielding has been developed [Senior and Blanc, 1984]. This model can be used to interpret the subauroral electric fields observed on November 11, 1981.

A study is under way to model the convection and electron density measurements from Chatanika and Millstone Hill on June 27, 1981. This effort uses the convection and ionospheric models described by Schunk and Raitt [1980] and Sojka et al. [1981]. It is part of a systematic extension of these comparisons from one radar [Sojka et al., 1983] to two, and then three, radars.

\section{DATA AVAILABILITY}

The MITHRAS data set of coincident auroral zone observations is available to interested scientists. The exchange of data among groups is facilitated by the adoption of a simple, but general, tapeformatting procedure. It is the procedure proposed for the incoherent-scatter data base at the National Center for Atmospheric Research. Data exchange is further eased by having all the incoherent-scatter data centrally available at SRI International. Scientists interested in using this data set should contact either of the first two authors of this paper.

\section{CONCLUSIONS}

An intensive campaign of coordinated auroral zone observations using three incoherent-scatter radars (Chatanika, Millstone Hill, and EISCAT) took place between May 1981 and June 1982. Coincident measurements were also made with STARE and the DE satellite. The purpose of these observations is to acquire a better understanding of the magnetosphere-ionosphere-thermosphere interac- 
tions by monitoring the auroral zone from stations widely separated in longitude.

Three types of MITHRAS experiments were conducted, each with a different temporal and spatial resolution. The exact times of observations and an indication of the magnetic activity are given in the catalog of MITHRAS experiments. This unique data set is open to the scientific community, and analyses by several groups are under way.

Acknowledgments. Research with the Chatanika and Millstone Hill facilities was supported by AFSOR contract F49620-81-C0042 and by NSF grants ATM 81-17792 and ATM 78-23658. Work at Utah State University was supported by AFOSR grant ATM 82-0093. EISCAT is supported by the Suomen Akatemia (Finland), the Centre National de la Recherche Scientifique (France), the Max-Planck Gesellschaft (West Germany), the Norges Almenvitenskaplige Forskingsrod (Norway), the Naturvetenskapliga Forskningsrodet (Sweden), and the Science Research Council (United Kingdom). The contributions of the staffs at the respective facilities are gratefully acknowledged.

\section{REFERENCES}

Alcaydé, D., J. Fontanari, and P. Bauer, High-latitude neutral temperature and concentration measurements from the first EISCAT incoherent-scatter observations, Ann. Geophys., 38, 473-479, 1982.

Alcaydé, D., J. Fontanari, P. Bauer, and O. de la Beaujardière, Some properties of the auroral thermosphere inferred from initial EISCAT observations, Radio Sci., 18, 881-886, 1983.

Baron, M. J., and R. H. Wand, $F$ region ion temperature enhancements resulting from Joule heating, J. Geophys. Res., 88, 41144118, 1983.

de la Beaujardière, O., V. Wickwar, C. Leger, M. McCready, and M. Baron, The software system for the Chatanika incoherentscatter radar, technical report, NSF grant ATM 782358, SRI project 8358, SRI International, Menlo Park, Calif., 1980.

de la Beaujardière, O., R. Vondrak, R. Heelis, W. Hanson, and R. Hoffman, Auroral arc electrodynamic parameters measured by AE-C and the Chatanika radar, J. Geophys. Res., 86, 4671-4685, 1981.

de la Beaujardière, O., M. J. Baron, V. B. Wickwar, C. Senior, and J. V. Evans, MITHRAS: A program of simultaneous radar observations of the high-latitude auroral zone, final report, contract F49620-81-C-0042, Dep. of Air Force, Bolling Air Force Base, Washington, D. C., 1982.

de la Beaujardière, O., J. Holt, and E. Nielsen, Early MITHRAS results: The electric field response to substorms, Radio Sci., 18 , 981-987, 1983a.

de la Beaujardière, O., G. Caudal, and J. Holt, MITHRAS observations of the nighttime $F$-region ionization (abstract), Eos Trans. $A G U, 64,777,1983 b$.

Elkins, T. J., An empirical model of the polar ionosphere, Rep. AFCRL-TR-73-0331, Air Force Cambridge Res. Lab., Hanscom Field, Bedford, Mass., 1973.

Evans, J. V., J. M. Holt, and R. H. Wand, Millstone Hill incoherent scatter observations of auroral convection over $60^{\circ} \leq \Lambda \leq 75^{\circ}, 1$, Observing and data reduction procedures, $J$. Geophys. Res., 84, 7059-7074, 1979.

Evans, J. V., J. M. Holt, W. L. Oliver, and R. H. Wand, The fossil theory of nighttime high latitude $F$ region troughs, $J$. Geophys. Res., 88, 7769-7782, 1983.

Feldstein, Y. I., and G. V. Starkov, Auroral oval in the IGY and IQSY period and a ring current in the magnetosphere, Planet. Space Sci., 16, 129, 1968.

Folkestad, K., T. Hagfors, and S. Westerlund, EISCAT: An updated description of technical characteristics and operational capabilities, Radio Sci., 18, 867-879, 1983.

Foster, J. C., An empirical electric field model derived from Chatanika radar data, J. Geophys. Res., 88, 981-987, 1983.

Foster, J. C., Ionospheric signatures of magnetospheric convection, J. Geophys. Res., 89, 855-865, 1984.

Foster, J. C., J. R. Doupnik, and G. S. Stiles, Large-scale patterns of auroral ionospheric convection observed with the Chatanika radar, J. Geophys. Res., 86, 11,357-11,371, 1981.

Greenwald, R. A., W. Weiss, E. Nielsen, and N. R. Thomson, STARE: A new radar auroral backscatter experiment in northern Scandinavia, Radio Sci., 13, 1021-1039, 1978.

Heelis, R. A., J. C. Foster, O. de la Beaujardière, and J. Holt, Multistation measurements of high-latitude ionospheric convection, J. Geophys. Res., 88, 10,117-10,127, 1983.

Holt, J., R. Wand, and J. Evans, Millstone Hill measurements on February 26, 1979 during solar eclipse and formation of a midday F-region trough, J. Atmos. Terr. Phys., in press, $1983 a$.

Holt, J. M., J. V. Evans, and R. H. Wand, Millstone Hill studies of the trough: Boundary between the plasmapause and magnetosphere or not?, Radio Sci., 18, 947-954, 1983b.

Kamide, Y., et al., Global distribution of ionospheric and fieldaligned currents during substorms as determined from six IMS meridian chains of magnetometers: Initial results, $J$. Geophys. Res., 87, 8228-8240, 1982.

Leadabrand, R. L., M. J. Baron, J. Petriceks, and H. F. Bates, Chatanika, Alaska, auroral-zone incoherent-scatter facility, Radio Sci., 7, 747-756, 19.72.

Oliver, W. L., J. M. Holt, R. H. Wand, and J. V. Evans, Millstone Hill incoherent scatter observations of auroral convection over $60^{\circ}<\Lambda<75^{\circ}, 3$, Average patterns versus $K p$, J. Geophys. Res., $88,5505-5516,1983$.

Rino, C. L., A. Brekke, and M. J. Baron, High-resolution auroral zone $E$ region neutral wind and current measurements by incoherent-scatter radar, J. Geophys. Res., 82, 2295-2304, 1977.

Schunk, R. W., and W. J. Raitt, Atomic nitrogen and oxygen ions in the daytime high-latitude $F$ region, J. Geophys. Res., 85, $1255-1272,1980$.

Senior, C., Courants alignés, précipitations diffuses et électrojets dans le secteur nuit de haute latitude, paper presented at GRECO Conference, Centre Natl. d'Etud. des Télécommun., Grenoble, France, 1982.

Senior, C., and M. Blanc, On the control of magnetospheric convection by the spatial distribution of ionospheric conductivities, J. Geophys. Res., 89, 261-284, 1984.

Sojka, J. J., W. J. Raitt, and R. W. Schunk, A theoretical study of the high-latitude winter $F$ region at solar minimum for low magnetic activity, J. Geophys. Res., 86, 609-621, 1981.

Sojka, J. J., R. W. Schunk, J. V. Evans, J. M. Holt, and R. H. Wand, Comparison of model high-latitude electron densities with Millstone Hill observations, J. Geophys. Res., 88, 77837793, 1983.

Wickwar, V. B., Chatanika radar measurements, in Atmospheres of Earth and the Planets, edited by B. M. McCormac, pp. 111-124, D. Reidel, Hingham, Mass., 1975.

Wickwar, V. B., O. de la Beaujardière, and W. Kofman, Meridion- 
al winds at Chatanika and EISCAT during project MITHRAS, paper presented at the EISCAT Workshop, Centre Natl. d’Etud. des Télécommun., Aussois, France, Sept. 5, 1983.

D. Alcaydé, Centre d'Etude Spatiale des Rayonnements, 11 Avenue du Colonel Roche, 31029 Toulouse Cedex, France.

P. Bauer, M. Blanc, G. Caudal, and C. Senior, CNET/CRPE, 38-40 Rue du Général Leclerc, 92131 Issy-les-Moulineaux, France.
M. J. Baron, EISCAT Scientific Association, Box 705, S-981 27 Kiruna, Sweden.

O. de la Beaujardière and V. B. Wickwar, SRI International, Menlo Park, CA 94025.

J. Foster, J. Holt, W. L. Oliver, and R. M. Wand, NEROC, Haystack Observatory, Westford, MA 01886.

R. Heelis, University of Texas at Dallas, Richardson, TX 75080.

E. Nielsen, Max-Planck-Institut für Aeronomie, D-3411 Katlenburg Lindau 3, Federal Republic of Germany. 